\title{
Yatılı Bölge Lisesi Kız Öğrencilerinin Kansere İlişkin Bilgileri ve Kanserden Korunma Davranışları
}

\author{
Mine Bekar ${ }^{1} \oplus$, Funda Evcili² ${ }^{2}$, İlknur Bilgin $^{1} \oplus$
}

'Sivas Cumhuriyet Üniversitesi, Ebelik Bölümü, Sivas, Türkiye

${ }^{2}$ Sivas Cumhuriyet Üniversitesi, Çocuk Gelişimi ve Gençlik Hizmetleri, Sivas, Türkiye

Mine Bekar, Dr. Öğr. Üyesi Funda Evcili, Dr. Öğr. Üyesi İlknur Bilgin, Öğr. Üyesi

İletişim:

Dr. Öğr. Üyesi Mine Bekar

Sivas Cumhuriyet Üniversitesi, Ebelik Bölümü, Sivas, Türkiye

Tel: $+903462191010 / 1352$

E-Posta:minebekar@gmail.com

Gönderilme Tarihi : 16 Aralık 2018

Revizyon Tarihi : 16 Aralık 2018

Kabul Tarihi : 09 Şubat 2019
ÖZET

Amaç: Kanserden korunmanın en basit ve en etkili yolu sağıkıı yaşam konusunda gerekli bilgiye ve davranışlara sahip olmaktır. Bilgi ve davranış değişikliği kazandırmak için en uygun zaman ise gençlik dönemidir. Bu araştırmanın amacı, kanser bilgisini artırma ve kanserden korunmaya yönelik davranışlar kazandırmaya yönelik eğitim programının lisede okuyan kız öğrencilerin bilgi ve davranışları üzerine etkisini incelemektir.

Yöntem: Araştırma, ön test-son test kontrol grupsuz müdahale araştırması türündedir. Örneklemi 410 kız öğrenci oluşturmuştur. Ön test uygulamasının ardından öğrencilere üç hafta boyunca (12 saat) kanser bildiğini artırma ve kanserden korunma davranışları kazandırmaya yönelik eğitim verilmiştir. Eğitimden bir ay sonra son test uygulaması yapılmıştır.

Bulgular: Araştırmaya katılan öğrencilerin yaş ortalamasının 15,4 40,62 olduğu; \%19,5'inin ailesinde kanser tanııı alan bir yakını bulunduğu saptanmıştır. Öğrencilerin \%12'sinin kanser belirtileri ve kanserden korunma konusunda bilgi almadığı belirlenmiştir. Öğrencilerin \%58'i bilgilerini "yetersiz" bulmaktadır. Eğitim programı sonrasında öğrencilerin bilgi puan ortalamalarının ve sağıkılı yaşam biçimi davranışlarına sahip olma oranlarının arttı̆̆ı belirlenmiştir $(p<0,05)$.

Sonuç: Genç insanların kanserden korunmalarını sağlamak için kansere ilişkin bilgi düzeylerinin artırılması gereklidir. Öğrenilen bilgilerin sağlıklı yaşam davranışlarına dönüştürülmesi ise bu sürecin önemli bir bileșenidir. Sağlık profesyonelleri, gençlerin ve gençler aracılığı ile toplumun kanser hastalığına yönelik bilgilerinin artııımasında ve sağlıklı yaşam biçimi davranışlarının kazandııımasında önemli roller üstlenirler.

Anahtar sözcükler: Kanser, bilgi, davranış, eğitim, korunma

CANCER RELATED KNOWLEDGE AND CANCER PREVENTION BEHAVIORS OF FEMALE STUDENTS OF A BOARDING HIGH SCHOOL

ABSTRACT

Objective: The simplest and most effective way to prevent cancer is to have the necessary knowledge and behaviors about healthy life. The best time to gain knowledge and behavior changes is the youth period. The aim of this study is to determine the effect of "training to increase cancer knowledge and cancer prevention behaviors" on female students of a boarding high school.

Methods: This pre-posttest intervention research has a sample consisted of 410 female students. After the pre-test, students were given training for 3 weeks ( 12 hours). After a month of training, the post-test was applied to the students.

Results: The mean age of the students was found to be $15.4 \pm 0.62$. $19.5 \%$ of the students have a relative who has a cancer diagnosis in the family. It was determined that $12 \%$ of the students didn't receive knowledge of protection/prevention from cancer and cancer symptoms. $58 \%$ of the students find their knowledge to be "insufficient". After the training program, students' knowledge score mean and healthy lifestyle behaviors increased $(p<0.05)$.

Conclusion: To ensure that young people are protected from cancer, their knowledge of cancer needs to be increased. Transformation of the learned information into healthy life behaviors is an important component of this process. Health professionals provide important contributions to the society in increasing the knowledge level for cancers and gaining healthy living behaviors.

Keywords: Cancer, knowledge, behavior, education, prevention 
$\mathbf{V}$ ücudumuzdaki sağlıklı hücreler bölünebilme yeteneğine sahiptirler. Yaşamın ilk yıllarında hücreler daha hızlı bölünürken, erişkin yaşlarda bölünme hızı yavaşlamaktadır. Bununla birlikte hücrelerin bölünebilme yetenekleri sınırlıdır, sonsuz kere bölünemezler. Hücreler bölünebilme yeteneğini tamamladıklarında ise ölürler. Buna apoptosis yani hücrenin programlı ölümü denir. Kanser, hücrelerin anormal bölünmesi ve büyümesidir. Sağlıklı hücrelerin replikasyonu bir noktada dururken, genlerdeki mutasyon nedeniyle kanser hücreleri büyümeye ve kontrolsüz bir şekilde bölünmeye devam eder. Kontrol edilemeyen hücre bölünmesi devam ettikçe, daha fazla mutasyon meydana gelir ve kanser vücudun diğer bölgelerine yayılım gösterir. Böylelikle, sağlıklı dokular mutant hücreler tarafından istila edilir ve organlar normal olarak işlev göremez (1). Kanser dünyada ölümle sonuçlanan en yaygın hastalıklardan biridir. Sigara, fiziksel hareketsizlik, ileri yaş, sağlıksız besinlerin tüketimi ve üreme fonksiyonlarındaki değiş̧iklikler gibi pek çok değişken kanser vakalarını artırmaktadır. Dünya genelinde kanser tanısı konan 14,1 milyon insan olduğu ve 2012 yılı itibariyle 8,2 milyon kişinin kanser nedeniyle öldüğü tahmin edilmektedir (2). Ayrıca, Dünya Sağlık Örgütü (WHO), dünya genelinde kanserden etkilenen insanların sayısının 2020 yılına kadar \%50 artacağını öngörmektedir (3). Tüm dünyada olduğu gibi Türkiye'de de kanser insidansı günden güne artmaktadır. Türkiye'de kanser insidansı gelişmiş ülkelerden daha düşük olmasına rağmen, dünya ortalamasından yüksektir. Ülkede 2013 yılında, erkeklerde yüz bin kişi başına 267,9 iken, kadınlarda yüz binde 186,5 olup toplam kanser insidansı 227,2'dir (4). Kadınlarda en sık kanser türü meme kanseri iken, erkeklerde en sık görülen kanser türü akciğer ve prostat kanseridir. Çocuklar arasında en yaygın kanser tipi ise lösemidir. 14-15 yaşlarında olan erkek ve kız adölesanlar arasında testis ve tiroid kanserleri görülme sıklığı da fazladır (4).

Sağlıklı bir yaşam tarzını benimsemek, kanser gibi birçok hastalığı önleyebilir (3). Bu nedenle, toplumun bilinçlendirilmesi, kansere karşı korunma ve kanserle mücadele için çok önemlidir. Büyüme ve gelişme süreçlerinin en hızlı yaşandığı ve yetişkinlikteki birçok alışkanlığın/davranışın temellerinin atıldığı erken adölesan dönemden itibaren kansere ilişkin farkındalığı arttıracak, risk faktörlerini ve hastalık semptomlarını tanıtacak, kanser nedenleri ve kanseri önleme yolları hakkında bilgi kazandıracak kapsamlı sağlık eğitimlerine ihtiyaç vardır $(5,6)$. Adölesanların kanser bilincinin artırılması, sağlıklı yaşam tarzlarını benimsemelerine ve erken tanı süreçlerine katkı sağlamaktadır (7). Literatürde yetişkinlerin kansere ilişkin farkındalığını artırmayı amaçlayan çok sayıda çalışma bulunmaktadır. Ancak adölesanlar üzerinde benzer amaçla yapılan çalışma sayısı sınırlıdır. Bununla birlikte veriler, kansere yönelik sağlık eğitimi programlarının bireylerin bilgi, tutum ve davranışları üzerinde olumlu etkileri olduğunu göstermektedir (8-11). Sağlık profesyonelleri "eğitici" rollerini kullanarak adölesanların büyüme ve gelişmesini sağlıklı bir biçimde tamamlanmasına yardımcı olmak, adölesanlara pozitif sağlık algısı kazandırmak, olumlu tutum ve davranışlar geliştirmek için çalışmalıdır. Böylelikle hem adölesanların hem de toplumun sağlığının korunmasını, sürdürülmesini ve geliştirmesini sağlamak mümkün olacaktır. Bu çalışmanın amacı, kanser hastalığına ilişkin bilgi düzeyini artırma ve kanserden korunma davranışı kazandırmaya yönelik eğitim programının yatılı bölge lisesinde okuyan kız öğrencileri üzerine etkisini incelemektir.

\section{Yöntem}

Araştırmanın tipi, yapıldığı yer ve zaman

Araştırma, ön test - son test kontrol grupsuz desende müdahale araştırmasıdır. Araştırma, Aralık 2016 - Şubat 2017 tarihleri arasında bir yatılı bölge lisesinde yürütülmüştür.

\section{Araştırmanın evreni ve örneklemi}

Araştırmanın evrenini yatılı bölge lisesinde okuyan $523 \mathrm{kız}$ öğrenci; örneklemi ise ön test ve son test uygulamasının her ikisine katılan 410 kız öğrenci oluşturmuştur.

\section{Veri toplama araçları}

Araştırmanın verileri, Kişisel Bilgi Formu, Kansere IIlişkin Bilgileri Belirleme Formu ve Kanserden Korunmaya Yönelik Davranışları Belirleme Formu kullanılarak toplanmıştır.

Kişisel bilgi formu: Formda, öğrencilerin bazı sosyodemografik (yaş, anne/baba eğitim düzeyi, anne/baba mesleği, aile tipi vb.), kanser belirtileri ve kanserden korunma konusunda bilgi edinme yolları, bilgi kaynakları, ailede kanser öyküsü olup olmadığı ve kanserle ilgili bilgi düzeylerini nasıl değerlendirdiklerini belirlemeye yönelik toplam 14 soru yer almaktadır.

Kansere ilişkin bilgileri değerlendirme formu: Form, araştırmacılar tarafından öğrencilerin kansere ilişkin sahip olduğu bilgileri değerlendirmek amacıyla oluşturulmuştur. Uzman görüşü yoluyla formun kapsam geçerliliği değerlendirilmiştir. Uzmanların önerileri doğrultusunda formlarda yer alan maddelerde düzeltmeler yapılmıştır. Formda 21 ifade bulunmaktadır. Her ifadenin karşısında "doğru", "yanlış" ve "bilmiyorum" olmak üzere üç seçenek yer almaktadır. Katılımcının doğru işaretlediği her bir seçenek "1", yanlış işaretlediği ya da boş bıraktığı her seçenek 
"0" puan ile puanlanmıştır. Formdan alınabilecek en düşük puan 0 en yüksek puan 21'dir. Toplam puanın artması halinde katılımcının kansere ilişkin bilgi düzeyinin yüksek olduğu şeklinde yorumlanmıştır.

\section{Kanserden korunmaya yönelik davranışları değer-} lendirme formu: Form, araştırmacılar tarafından öğrencilerin kanserden korunmaya yönelik davranışlarını değerlendirmek amacıyla oluşturulmuştur. Uzman görüşü yoluyla formun kapsam geçerliliği değerlendirilmiştir. Uzmanların önerileri doğrultusunda formlarda yer alan maddelerde düzeltmeler yapılmıştır. Üçlü Likert tipi formda toplam 14 ifade yer almaktadır. Her ifadenin karşısında katılmıyorum (0 puan), kısmen katılıyorum (1 puan), katılıyorum (2 puan) olmak üzere üç seçenek yer almıştır. Formdan alınabilecek en düşük puan 0 en yüksek puan 28'dir. Toplam puanın artması halinde katılımcının kanserden korunmaya yönelik davranışlara sahip olduğu kabul edilmiştir.

\section{Araştırmanın etik yönü}

Anket formları, II Milli Eğitim Müdürlüğü'nden izinlerin alınmasının ardından 2016-2017 eğitim-öğretim yılı bahar döneminde uygulanmıştır. Okulun öğrenci sayılarına ilişkin veriler okul idaresinden sağlanmıştır. Araştırma kapsamındaki öğrencilerin haklarının korunması için araştırma verilerini toplamaya başlamadan önce araştırmanın yapılma amacı açıklanarak "Aydınlatılmış Onam" ilkesi, elde edilen bilgilerin gizli tutulacağı belirtilerek "Gizlilik ve Gizliliğin Korunması" ilkesi, araştırmaya gönüllü olarak katılmak isteyenlerin alınması ile de "Özerkliğe Saygı" ilkesini içeren etik ilkeler yerine getirilmiştir. Ayrıca anket uygulamasının bitiminden sonra öğrencilerin soruları cevaplandırılarak konu ile ilgili bilgiler de verilmiştir. Araştırmaya katılmayı reddeden öğrenci olmamıştır.

\section{Araştırmanın uygulanması}

Eğitim programı öncesinde 20 öğrenciye veri toplama araçlarının ön uygulaması yapılmıştır. Uygulama sonuçları değerlendirilmiş ve veri toplama araçlarının anlaşılır olduğu görüldükten sonra uygulanmasına karar verilmiştir. Ön uygulama yapılan öğrenciler örnekleme alınmamıştır. Kansere İlişkin Bilgileri Belirleme Formu ve Kanserden Korunmaya Yönelik Davranışları Belirleme Formu'nun ön test uygulaması sırasında katılımcılardan her bir ifadeyi dikkatle okumaları ve kendilerine uygun olduğunu düşündükleri seçeneği işaretlemeleri istenmiştir. Ön test uygulamasından sonra öğrencilere araştırmacılar tarafından üç hafta boyunca toplam 12 saatten oluşan kanser bilgisini artırmak ve kanserden korunmaya yönelik davranışlar kazandırmak amacıyla eğitim verilmiştir. Eğitimden bir ay sonra veri toplama araçları öğrencilere tekrar uygulanmıştır. Veri toplama araçlarının doldurulması sırasında öğrenciler arasındaki bilgi kontaminasyonunu önlemek amacıyla araştırmacılar öğrencilerin yanlarında bulunmuş ve formlar öğrenciler tarafından doldurulduktan sonra araştırmacı tarafından toplanmıştır.

\section{Araştırmanın sınırlılıkları}

Araştırmada, öğrencilerden veri toplama formlarına isimlerini yazmaları, ismini yazmak istemeyenlerden ise unutmayacakları bir rumuzu kullanmaları istenmiştir. Ancak veri toplama araçlarının son uygulanma aşamasında bazı öğrenciler rumuzlarını unutmuştur. Rumuzunu unutan öğrencilerin ön test ve son test veri toplama araçları eşleştirilememiş, bu nedenle bazı öğrenciler araştırma kapsamından çıkarılmıştır. Bununla birlikte ön test uygulamasına katılmasına karşın "okul devamsızlığı" nedeniyle son test uygulamasına katılamayan öğrenciler olmuştur.

\section{Araştırmanın değişkenleri}

Bağımlı Değişken: Öğrencilerin kansere ilişkin bilgi düzeyleri ve kanserden korunmaya yönelik davranışları

Bağımsız Değişken: Kansere ilişkin bilgi düzeyini artırmaya ve kanserden korunmaya yönelik sağlıklı yaşam biçimi davranışları kazandırma eğitimi

Kontrol Değişkenleri: Öğrencilerin yaşı, aile tipi, anne ve babanın çalışma durumu, anne ve babanın eğitim durumu, kanserle ilgili bilgi alma durumu, bilgilerini yeterli bulma durumları kontrol değişkenlerini oluşturmuştur.

\section{Verilerin değerlendirilmesi}

Elde edilen veriler, SPSS 22.0 for Windows paket programında analiz edilmiştir. Çalışma verileri değerlendirilirken tanımlayıc istatistiksel yöntemlerin (sayı, yüzde, ortalama, standart sapma) yanı sıra, Pearson Çarpım Moment Korelasyon analizi, iki ortalama arasındaki farkın önemlilik testi (t testi) kullanılmıştır. Sonuçlar \%95'lik güven aralığında, anlamlılık $p<0,05$ düzeyinde değerlendirilmiştir.

\section{Bulgular}

Araştırmaya katılan öğrencilerin yaş ortalaması 15,4 40,62 olup \%23,9'u il merkezinde yaşamaktadır. Öğrencilerin annelerinin \%43,9'unun babalarının \%37,3'ü ilkokul ve altında eğitim düzeyine sahiptir. Annelerin $\% 21,5^{\prime} \mathrm{i}$, babaların tamamı gelir getiren bir işte çalışmaktadır. Öğrencilerin $\% 71,5^{\prime} \mathrm{i}$ çekirdek aileye sahiptir. 
Öğrencilerin, \%19,5'inin ailesinde kanser tanısı alan bir yakını bulunduğu saptanmıştır. Öğrencilerin \%88'inin kanser belirtileri ve kanserden korunma konusunda bilgi aldığı, yalnızca \%42,0'ının konuya ilişkin bilgilerini yeterli buldukları belirlenmiştir. Öğrencilerin kanserle ilgili bilgi edindikleri kaynaklar arasında ilk sırada internet/televizyonu $(\% 83,4)$ gösterdikleri belirlenmiştir. Öğrencilerin yalnızca \%36'sı sağlık profesyonellerini bilgi kaynağı olarak göstermiştir (Tablo 1).

Öğrencilerin eğitim öncesi 5,9 9 3,52 olan kanser ilişkin bilgi puan ortalaması eğitim sonrası $12,6 \pm 6,06$ 'dır ( $\mathrm{t}=21,09$; $p=0,000$ ). Öğrencilerin eğitim öncesi $8,1 \pm 2,27$ olan kanserden korunmaya yönelik davranış puan ortalaması eğitim sonrası $18,2 \pm 3,13^{\prime} d ı r(t=46,71 ; p=0,000)$. Öğrencilerin program öncesine göre kansere ilişkin bilgi puanı ortalamasının 6,75 22,48 puan; kanserde korunmaya ilişkin davranış puan ortalamasının 10,1 $\pm 4,38$ puan arttığı belirlenmiştir. Program öncesi ve sonrası toplam puan ortalaması arasındaki farkın istatistiksel olarak önemli olduğu belirlenmiştir $(p<0,05)$ (Tablo 2$)$.

\section{Tablo 1. Öğrencilerin kanserle ilgili bazı özelliklerine göre dağıımı $(n=410)$}

\begin{tabular}{lc} 
Özellikler & $\boldsymbol{n}(\%)$ \\
\hline Ailede kanser öyküsü olma & \\
Var & $80(19,5)$ \\
Yok & $330(80,5)$ \\
\hline Kanserle ilgili bilgi alma & \\
Evet & $361(88,0)$ \\
Hayır & $49(12,0)$ \\
\hline Kanserle ilgili bilgilerini yeterli bulma & \\
Yeterli & $172(42,0)$ \\
Yetersiz & $238(58,0)$ \\
\hline Kanserle ilgili bilgi kaynakları* & \\
İnternet/televizyon & $342(83,4)$ \\
Kitap/gazete/dergi & $244(59,5)$ \\
Aile & $240(58,5)$ \\
Sağlık personeli & $148(36,0)$ \\
Öğretmen & $102(24,8)$ \\
\hline *Birden fazla seçenek işaretlenmiş; yüzdeler $n$ üzerinden alınmıştır.
\end{tabular}

Tablo 2. Öğrencilerin eğitim öncesi ve sonrası kansere ilişkin bilgi testi

ve kanserden korunma davranışları testi toplam puanı ve fark ortalamaları $(n=410)$

\begin{tabular}{|l|c|c|c|c|c|}
\hline & $\begin{array}{c}\text { Teste ait } \\
\text { min-max } \\
\text { puan }\end{array}$ & $\begin{array}{c}\text { Eğitim } \\
\text { öncesi } \\
\overline{\boldsymbol{x}} \pm \text { SD }\end{array}$ & $\begin{array}{c}\text { Eğitim } \\
\text { sonrası } \\
\overline{\boldsymbol{x}} \pm \text { SD }\end{array}$ & $\boldsymbol{t} / \boldsymbol{p}$ & Fark \\
\hline $\begin{array}{l}\text { Kanser } \\
\text { bilgisi }\end{array}$ & $0-21$ & $5,9 \pm 3,52$ & $12,6 \pm 6,06$ & $21,09 / 0,000$ & $6,75 \pm 2,48$ \\
\hline $\begin{array}{l}\text { Kanserden } \\
\text { korunma } \\
\text { davranıŞı }\end{array}$ & $0-28$ & $8,1 \pm 2,27$ & $18,2 \pm 3,13$ & $46,71 / 0,000$ & $10,1 \pm 4,38$ \\
\hline
\end{tabular}

Ailesinde kanser tanısı olan, il merkezinde yaşayan, anne eğitim düzeyi ortaokul ve üzerinde olan öğrencilerin kanser bilgisi ve kanserden korunma davranışı toplam puan fark ortalaması arasında istatistiksel olarak önemli fark olduğu belirlenmiştir $(p<0,05)$ (Tablo 3 ).

Tablo 4'de öğrencilerin kanser bilgisi ile kanserden korunma davranışı puanları arasındaki ilişsiyi belirlemek üzere yapılan Pearson Çarpım Moment Korelasyon Analizi sonuçları verilmiştir. Tabloya göre, öğrencilerin eğitimi

Tablo 3. Öğrencilerin eğitim öncesi ve sonrası kanser bilgisi ve kanserden korunma davranışı puan fark ortalamalarının bazı özelliklere göre dağılımı

\begin{tabular}{|c|c|c|}
\hline & Kanser bilgisi & $\begin{array}{c}\text { Kanserden korunma } \\
\text { davranışı }\end{array}$ \\
\hline Özellikler & $\bar{x} \pm S D$ & $\bar{x} \pm S D$ \\
\hline \multicolumn{3}{|l|}{ Yaşadığı yer } \\
\hline il $(n=98)$ & $6,13 \pm 3,56$ & $12,97 \pm 6,08$ \\
\hline İlçe/köy $(n=312)$ & $4,88 \pm 3,51$ & $10,80 \pm 5,92$ \\
\hline$t / p$ & $2,68 / 0,041$ & $1,67 / 0,048$ \\
\hline \multicolumn{3}{|l|}{ Anne eğitimi } \\
\hline İlkokul ve altı $(n=180)$ & $5,49 \pm 3,40$ & $9,37 \pm 4,45$ \\
\hline Ortaokul ve üzeri $(n=230)$ & $6,30 \pm 3,57$ & $10,61 \pm 4,25$ \\
\hline$t / p$ & $2,30 / 0,021$ & $2,00 / 0,046$ \\
\hline \multicolumn{3}{|l|}{ Baba eğitimi } \\
\hline İlkokul ve altı $(n=153)$ & $6,06 \pm 2,10$ & $10,15 \pm 4,42$ \\
\hline Ortaokul ve üzeri $(n=257)$ & $7,90 \pm 3,20$ & $11,00 \pm 3,18$ \\
\hline$t / p$ & $2,27 / 0,005$ & $0,225 / 0,058$ \\
\hline \multicolumn{3}{|l|}{ Ailede kanser öyküsü } \\
\hline $\operatorname{Var}(n=80)$ & $7,85 \pm 2,07$ & $12,43 \pm 2,30$ \\
\hline Yok $(n=330)$ & $5,91 \pm 3,58$ & $10,02 \pm 3,12$ \\
\hline$t / p$ & $0,339 / 0,690$ & $2,04 / 0,041$ \\
\hline \multicolumn{3}{|c|}{ Kanserle ilgili bilgilerini yeterli bulma durumu } \\
\hline Yetersiz $(n=172)$ & $7,53 \pm 2,10$ & $11,3 \pm 2,48$ \\
\hline Yeterli $(n=238)$ & $6,18 \pm 2,48$ & $9,92 \pm 3,24$ \\
\hline$t / p$ & $2,090 / 0,037$ & $1,073 / 0,284$ \\
\hline
\end{tabular}

Tablo 4. Öğrencilerin kanser bilgisi ile kanserden korunma davranışı puanları arasındaki ilişki durumu

\begin{tabular}{lccc} 
& & \multicolumn{2}{c}{ Kanserden korunma davranışı } \\
\hline & & $\boldsymbol{r}^{*}$ & $\boldsymbol{p}$ \\
\hline \multirow{2}{*}{ Kanser bilgisi } & Eğitim öncesi & $-0,434$ & 0,001 \\
& Eğitim sonrası & $-0,615$ & 0,001 \\
\hline \multirow{2}{*}{ *Pearson çarpım moment korelasyon analizi } & &
\end{tabular}


programı öncesi ve sonrası kanser bilgi puanları ile kanserden korunma davranışı puanları arasında istatistiksel açıdan pozitif yönde anlamlı bir ilişki saptanmıştır $(p<0,05)$. $\mathrm{Bu}$ bulgu, öğrencilerin kanserle ilişkili konularda sahip oldukları bilgi düzeyi arttıkça kanserden korunma davranışlarının da arttığı şeklinde yorumlanabilir.

\section{Tartışma}

Dünya genelinde sağlık ile ilişkili konular, okul müfredatlarının içerisinde kendisine öncelikli olarak yer bulamamaktadır. Okullar, çocukların var olan sınavlarını geçmesine odaklanmakta bu nedenle sanat, sağlık ve beden eğitimi yerine okuma ve matematik gibi belirli becerileri test eden derslere öncelik verilmektedir (12). Yapılan çalışmalar birçok ülkede "kanser" konusunun müfredata eklenmesi ya da ele alınma şekli açısından çeşitli problemlerin yaşandığını ortaya koymaktadır. Eğiticilerin kanser hakkında öğrencileri bilgilendirme noktasında isteksizlik yaşaması (9), eğiticilerin öğrencileri bilgilendirme konusunda istekli olmasına rağmen konuya ilişkin yeterli bilgiye sahip olmaması $(13,14)$ ya da kanser eğitimi ile ilgili konuların sadece lise müfredatında olması ve ilkokul müfredatında daha çok diğer hastalıkların ele alınması (6) bu problemlerden bazılarıdır. Türkiye'de ise öğrenciler dokuzuncu sınıfta "Sağlığa Zararlı Alışkanlıklar" olarak adlandırılan Ünite 5 kapsamında, kanseri sigara ile ilişkilendirmektedir. Ayrıca "Hastalıklarla İlgili Temel Kavramlar ve İlkeler" olarak adlandırılan Ünite 7, öğrencilere kanser risk faktörleri ve kanser belirtileri hakkında bilgi vermektedir. Ünitenin sonunda, öğrencilerin erken tanı ve kanser tedavisinin önemini açıklamaları ve önleme yollarını sıralamaları beklenmektedir (15).

Kansere ilişkin farkındalık kazandırmaya yönelik eğitimler yalnızca okullar tarafından değil sağlık profesyonelleri tarafından verilen sağlık eğitimleri yoluyla gerçekleştirilebilir. Sağlık profesyonelleri, bireylerin, kanser hastalığına ilişkin farkındalığının artırılmasını ve erken tanıya hizmet eden kendi kendine muayene becerisinin kazandırılmasını sağlayabilir. Buna karşın çalışmamızdaki öğrencilerin kanser hakkındaki bilgi kaynakları arasında sağlık profesyonelleri 4. sırada yer almaktadır. Gençlerin çeşitli faktörlerin etkisiyle sağlık profesyonellerini bilgi kaynağı olarak kullanmasının önünde bazı engeller bulunmaktadır. Örneğin Kyle ve ark.'nın (2012) çalışmasında öğrencilerin \%74'ü kanser olduğunu düşünse dahi çeşitli nedenlerle (kanser tanısı almaktan korkma, utanma, kanser hakkında konuşurken rahatsızlık kendisini rahatsız hissetme gibi) sağlık profesyonellerine başvurmakta zorlanacaklarını ifade etmiştir (7). Araştırmamızda öğrencilerin kansere ilişkin bilgi kaynakları arasında ilk sırada internet/televizyonun olduğu $(\% 83,4)$ belirlenmiştir Birkaç çalışmada da katılımcıların kanser hakkında bilgi edindikleri kaynaklar arasında ilk sıralarda "televizyon ve medya" geldiği belirlenmiştir $(16,17)$. Bu bulgular, sağlık profesyonellerinin gençleri kanser risk faktörleri, semptomları ve kansere karşı korunma yolları hakkında eğitmek için medyanın gücünü kullanmaları halinde eğitimlerin etkinliğinin artacağı şeklinde yorumlanabilir.

Çalışmamızda örneklemin tamamını kız öğrenciler oluşmuştur. Bu nedenle öğrencilerin cinsiyetine göre eğitimin etkinliği değerlendirilememiştir. Ancak araştırmalar, kız ve erkek öğrencilerin kanser konusundaki bilgi düzeyleri ve kansere ilişkin tutumlarının/davranışlarının birbirinden farklı olabildiğini göstermektedir $(7,9)$. Bu araştırmalardan elde edilen veriler, erkek öğrencilerin kanser belirtileri ve yaygın kanser türleri hakkındaki bilgi düzeylerinin kız öğrencilerden daha düşük olduğunu $(7,18)$; erkek öğrencilerin güneş altında daha fazla zaman geçirdiğini ve kız öğrencilerden daha az güneş koruyucu kullandığını (19), kız öğrencilerin ise erkeklere göre kanser hakkında olumsuz düşüncelere daha fazla sahip olduğunu ancak kansere karşı daha proaktif bir şekilde davranma eğiliminde olduklarını ortaya koymaktadır (9). Kansere ilişkin olumsuz duygular, gençlerin kanserden korunma amacıyla daha sağlıklı bir yaşam tarzının benimsenmesine katkı sağlayabilir ve gençlerin motivasyonunu artırabilir. Ayrıca veriler doğrultusunda, öğrencilere yönelik bir sağlık eğitimi programı hazırlanırken cinsiyet farklııklarının da göz önünde bulundurulmasına özen gösterilmesinin önemli olduğu söylenebilir.

Bu çalışmada öğrencilerin \%58'inin kanserle ilişkili bilgi düzeyini yetersiz bulduğu saptanmıştır. Çok sayıda araştırma öğrencilerin kanser konusunda bilgilerinin gelişmiş ülkelerde bile yetersiz olduğunu, birçok kanser türünü bilmediklerini göstermektedir $(17,20)$. Yapılan bir çalışmada, öğrencilerin kanser farkındalığının düşük olduğu; $\% 50$ 'sinin gençlerde ve çocuklarda en fazla teşhis edilen kanser türlerini bilmediği saptanmıştır (7). Sugisaki ve ark. (2014) tarafından Japonya'da ilkokul öğrencilerinin en çok akciğer kanserini, ortaokul ve lise öğrencilerinin ise lösemi ve meme kanserini bildiği belirlenmiştir. Ancak, aynı çalışmada öğrencilerin yaklaşık \%50'sinin yaygın kanser türlerini bile bilmedikleri ve bu durumun kanser eğitiminin yetersizliği ile ilişkili olduğu belirtilmiştir (6). Sherman ve Lane (2014), İngiltere'de yaptıkları çalışmada öğrencilerin diğer kanser türlerine göre akciğer kanseri risk faktörleri hakkında daha fazla bilgiye sahip olduğunu saptanmıştır (18). Karayurt ve ark. (2008), lisede okuyan kız öğrencilerin 
meme kanserinde risk faktörleri ve kendi kendine meme muayenesi konusunda bilgi düzeylerinin yeterli olmadığı belirlenmiştir. Öğrencilerin çok azı kendi kendine meme muayenesi yaptığını, önemli bir kısmı ise muayeneyi nasıl uygulayacaklarını bilmedikleri için yapamadığını ifade etmiştir (17). Keten ve ark. (2015), lise öğrencilerinin oral kanser hakkındaki bilgilerinin yeterli olmadığını ortaya koymuştur (21). Koç (2015), lisans öğrencilerinin \%83,2'sinin serviks kanserinin erken belirtileri hakkında hiçbir fikrinin olmadığını; \%87,0'ının kanser tedavisine erken tanı konmasının önemini bilmelerine rağmen serviks kanseri erken tanı yöntemlerini bilmediği belirlenmiştir (22). Gençler için bir kanser eğitimi programı geliştirmeden önce, mevcut bilgi düzeyini ve kansere karşı tutumlarını belirlemek, daha etkili bir eğitim programı geliştirmek için faydalı olacaktır ve kanser ile ilgili dikkat çekici noktaların öne çıkarılmasına katkı sağlayacaktır $(3,6,7,9)$. Adolesan dönemdeki eğitimler, sunulan bilgilerin içselleştirilmesi için değerli ve gereklidir. Ancak pek çok sağlık eğitimi programı, çocukların/gençlerin gereksinimlerine ve bilgi düzeylerine uygun içerikte hazırlanmadığı için etkili olamamaktadır. Bu çalışmada bir diğer önemli bulgu şudur; ailesinde ya da çevresinde kanser tanısı alan öğrencilerin bilgi puan ortalamaları daha yüksek ve sağlıklı yaşam biçimi davranışlarına daha fazla sahip olduğu belirlenmiştir. Bu veriyi destekler bir başka çalışmada da, bir kanser hastasını tanıyan katılımcıların kanser hakkında daha bilgili olduğu saptanmıştır (7).

Çalışmamızın ön test uygulamasında gençlerin \%48'i obezitenin; \%28'i sigara kullanımının, \%53'ü alkol kullanımının kansere neden olduğunu bilmediği belirlenmiştir. Öte yandan, Karayurt ve ark.'na (2008) göre lise öğrencilerinin meme kanseri ile obezite arasındaki ilişki hakkında yeterli bilgiye sahip olmadığı bulunmuştur (17). Heuckmann ve Asshoff (2014) çalışmasında katılımcıların sadece \%18,7'sinin aşırı kilo ve kanser arasında bir ilişki olduğunu bildiği saptanmıştır (9). Knighting ve ark. (2010) çalışmasında ise öğrenciler, kansere neden olduğu düşünülen risk faktörleri arasında en çok sigara ve güneşi göstermiştir (3). Kyle ve ark. (2012) çalışmasında katılımcıların \%68,5'inin yaş ile kanser arasında bir ilişki olmadığını düşündüğü

\section{Kaynaklar}

1. American Cancer Society (ACS), Cancer Facts \& Figures 2018 Atlanta: American Cancer Society; 2018. https://www.cancer.org/ content/dam/cancer-org/research/cancer-facts-and-statistics/ annual-cancer-facts-and-figures/2018/cancer-facts-andfigures-2018.pdf

2. Torre LA, Bray F, Siegel RL, Ferlay J, Lortet-Tieulent J, Jemal A. Global cancer statistics, 2012. CA Cancer J Clin 2015;65:87-108. [CrossRef] belirlenmiştir (7). Sherman ve Lane (2014), İngiltere'de yaptıkları çalışmada öğrencilerin yaklaşık yarısının (18); Koç (2015), öğrencilerin \%90'ının HPV'nin serviks kanseri için bir risk faktörü olabileceğini bilmediğini saptamıştır (22). Karayurt ve ark. (2008), lisede okuyan kız öğrencilerin meme kanseri için en çok bilinen risk faktörünün, "ailevi kanser öyküsü" olduğu belirlenmiştir. Keten ve ark. (2015), lise öğrencilerinin oral kanser için risk faktörü olarak bilinen "tütün kullanımının" erkek öğrenciler arasında yaygın olduğunu ortaya koymuştur (21). Gençlerin kansere neden olabilecek risk faktörlerine ilişkin bilgi düzeyinin yetersiz olması, kanserden korunma çabalarının yetersiz kalmasına neden olabilir. Bu çalışmada, öğrencilerin \%48'i "vücudun herhangi bir yerinde nedensiz şişlik ve sertlikler olmasını", \%56'sı "ben ve siğillerde ani büyüme ve değişiklik olmasını", \%52'si "yutma güçlüğü yaşanmasını", \%49'u "idrar ve dışkılama alışkanlıklarında değişiklik yaşanmasını" kanser belirtisi olarak bilmemektedir. Kyle ve ark. (2012) "şişlik veya şişme"nin gençler arasında en çok bilinen kanser semptomu olduğunu belirlemiștir. Veriler farklı ülkerde -ülkelerin gelişmişlik düzeyine bakılmaksızın- gençlerin kanserlerin risk faktörlerine ilişkin bilgi düzeylerinin yetersiz olduğunu göstermektedir (7).

\section{Sonuç ve Öneriler}

Bu çalışmada, kanser bilgisini artırma ve kanserden korunmaya yönelik davranışlar kazandırmaya yönelik eğitim programının sonrasında öğrencilerin bilgi puan ortalamalarının ve sağlıklı yaşam biçimi davranışlarına sahip olma oranlarının arttığı belirlenmiştir. Genç insanların kanserden korunmalarını sağlamak için kansere ilişkin bilgi düzeylerinin artırılması gereklidir. Öğrenilen bilgilerin sağlıklı yaşam davranışlarına dönüştürülmesi ise bu sürecin önemli bir bileşenidir. Sağlık profesyonelleri, gençlerin ve gençler aracılığı ile toplumun kanser hastalığına yönelik bilgilerinin artırılmasında ve sağlıklı yaşam davranışlarının kazandırılmasında önemli roller üstlenirler. Özelde gençlerin genelde ise toplumun sağlığının geliştirilmesi için sağlık profesyonelleri, gençlerin ilgisini çekecek ve bilgi gereksinimlerini karşılayacak sağlık eğitimlerini periyodik aralıklarla hayata geçirmek için çaba göstermelidir.

3. Knighting K, Rowa-Dewar N, Malcolm C, Kearney N, Gibson F. Children's understanding of cancer and views on health-related behaviour: A "draw and write" study. Child Care Health Dev 2011;37:289-99. [CrossRef]

4. Gültekin M, Boztaş $G$, Şimşek Utku E, Kavak Ergün A, Sevinç $A$, Tütüncü $S$, Dündar $S$, Seymen E. (editörler) Şencan I, İnce GN. T. C. Sağlık Bakanlığı Türkiye Halk Sağlığı Kurumu. Türkiye Kanser İstatistikleri. Ankara; 2016. 
5. Schernhammer E, Haidinger G, Waldhör T, Vargas R, Vutuc C. A study of trends in beliefs and attitudes toward cancer. J Cancer Educ 2010;25:211-6. [CrossRef]

6. Sugisaki $\mathrm{K}$, Ueda $\mathrm{S}$, Monobe $\mathrm{H}$, Yako-Suketomo $\mathrm{H}$, Eto $\mathrm{T}$, Watanabe M, Mori R. Cancer understanding among Japanese students based on a nationwide survey. Environ Health Prev Med 2014;19:395-404. [CrossRef]

7. Kyle RG, Forbat L, Hubbard G. Cancer awareness among adolescents in Britain: a cross-sectional study. BMC Public Health 2012;12:580. [CrossRef]

8. Soweid RAA, Kak FEL, Major SC, Karam DK, Rouhana A. Changes in health-related attitude and self-reported behaviour of undergraduate students at the american university of beirut following a health awareness course. Educ Health 2003;16:265-78. [CrossRef]

9. Heuckmann B, Asshoff R. German high school students' attitudes and interest in cancer and factors influencing proactive behaviour for cancer prevention. J Cancer Educ 2014;29:497-505. [CrossRef]

10. Wang D, Stewart D, Chang C, Shi Y. Effect of a school-based nutrition education program on adolescents' nutrition-related knowledge, attitudes and behaviour in rural areas of China. Environ Health Prev Med 2015;20:271-8. [CrossRef]

11. Haghani S, Shahnazi $H$, Hassanzadeh A. Effects of tailored health education program on overweight elementary school students' obesity-related lifestyle: a school-based interventional study. Oman Med J 2017;32:140-7. [CrossRef]

12. Morse LL. Let schools do it! Helping schools find a role in cancer prevention. J Adolesc Health 2013;52:S89-92. [CrossRef]

13. Carey P. Teachers' attitudes to cancer education: A discussion in the light of a recent English survey. J Cancer Educ 1992;7:153-61. [CrossRef]
14. Cribb A. School teachers' perceptions of relative importance of cancer education in the United Kingdom. J Cancer Educ 1990;5:2259. [CrossRef]

15. Milli Eğitim Bakanlığı. Teaching program of secondary school health course; 2012

16. Oakley A, Bendelow G, Barnes J, Buchanan M, Husain OAN. Health and cancer prevention: knowledge and beliefs of children and young people. BMJ 1995;310:1029-33. [CrossRef]

17. Karayurt Ö, Özmen D, Çakmakçı Çetinkaya A. Awareness of breast cancer risk factors and practice of breast self examination among high school students in Turkey. BMC Public Health 2008;8:359. [CrossRef]

18. Sherman SM, Lane EL. Awareness of risk factors for breast, lung and cervical cancer in a UK student population. J Cancer Educ 2014;30:660-3. [CrossRef]

19. Tempark T, Chatproedprai S, Wananukul S. Attitudes, knowledge, and behaviors of secondary school adolescents regarding protection from sun exposure: a survey in Bangkok, Thailand. Photodermatol Photoimmunol Photomed 2012;28:200-6. [CrossRef]

20. Gültekin M, Özgül N, Olcayto E, Tuncer M. Level of knowledge among Turkish people for cancer and cancer risk factors. J Turk Soc Obstet Gynecol 2011;8:57-61. [CrossRef]

21. Keten HS, Isik O, Guvenc N, Ersoy O, Celik M. Evaluation of the Level of Knowledge of Oral Cancer Among High School Students. J Cancer Educ 2015;32:79-84. [CrossRef]

22. Koç Z. University students' knowledge and attitudes regarding cervical cancer, human papillomavirus, and human papillomavirus vaccines in Turkey. J Am Coll Health 2015;63:13-22. [CrossRef] 